АртеменкоЛ. П.

канд. економ. наук, дочент

Піддубна А.С.

Національній технічний університет Україні «КПI»

\title{
ОРГАНІЗАЦІЙНО-ЕКОНОМІЧНИЙ МЕХАНІЗМ УПРАВЛІННЯ КОНКУРЕНТОСПРОМОЖНІСТЮ ПРОМИСЛОВОГО ПІДПРИЕМСТВА
}

\author{
ОРГАНИЗАЦИОННО-ЭКОНОМИЧЕСКИЙ МЕХАНИЗМ УПРАВЛЕНИЯ \\ КОНКУРЕНТОСПОСОБНОСТЬЮ ПРОМЫШЛЕННОГО ПРЕДПРИЯТИЯ
}

\section{ORGANIZATIONAL-ECONOMIC MECHANISM OF COMPETITIVENESS INDUSTRIAL ENTERPRISES}

\begin{abstract}
Стаття присвячена визначенню особливостей розробки організаційноекономічного механізму управління конкурентоспроможністю підприємства, охарактеризовано головні підсистеми управління. Визначено основні принципи оцінки організаційно-економічного механізму управління конкурентоспроможністю підприємства, які забезпечують ефективне управління підприємством та теоретичні аспекти управління конкурентоспроможністю підприємства.Проведено оцінювання складових організаційно-економічного механізму управління конкурентоспроможністю підприємства та обтрунтовано основні пропозииї щуодо прогнозування підвищення конкурентоспроможності на основі впровадженого механізму. Визначено, щцо організачійно-економічний механізм управління конкурентоспроможністю підприємства пов'язаний з розробкою та ефективним функиіонуванням підсистем управління. Запропоновано науково-методичні рекомендачіі щзодо вибору $i$ реалізачії конкретних організаційних, економічних та техніко-технологічних заходів, які створюють передумови забезпечення реальних конкурентних переваг підприємства в умовах нестабільного зовнішнього середовища.
\end{abstract}

Ключові слова: організаційно-економічний механізм, управління конкурентоспроможністю; принципи оцінки

Статья включает в себя определение особенностей разработки организационноэкономическогомеханизма управления конкурентоспособностью предприятия, охарактеризованы подсистемы управления. Определены основные принципы оценки организационно-экономического механизма управления конкурентоспособностью предприятия, которые обеспечат эфрфективное управление предприятием $u$ теоретические аспекты управления конкурентоспособностью предприятия. Проведена оценка составляющих организащионно - экономического механизма управления конкурентоспособностью предприятия и обоснованы основные предложения по прогнозированию повышения конкурентоспособности на основе внедренного механизма. Определено, что организационно-экономический механизм управления конкурентоспособностью предприятия связан с разработкой и эффрективным функционированием подсистем управления. Предложены научно - методические рекомендации по выбору и реализации конкретных организационных, экономических $u$ технико - технологических мероприятий, которые создают предпосылки обеспечения 
реальных конкурентных преимуществ предприятия в условиях нестабильной внешней cредbl.

Ключевые слова: организационно-экономический механизм, управление конкурентоспособностью, принципы оценки

The article includes defining features of organizational development-economic competitiveness of enterprise management mechanism, described management subsystem. The basic principles of assessing organizational - economic mechanism of the competitiveness of enterprises and ensure effective management and theoretical aspects of management of enterprise's competitiveness. Estimation of the components of the organizational and economic mechanism of the enterprise's competitiveness and proved the main proposals for improving the competitiveness of forecasting based embedded mechanism. It was determined that organizational- economic mechanism of competitive enterprises associated with the development and effective operation of management subsystems. Proposed scientific guidance on the choice and implementation of specific organizational, economic, technical and technological measures to create conditions to ensure real competitive advantage in an uncertain external environment.

Key words:organizational-economic mechanism, management of competitiveness, principles of assessment

Вступ. Конкурентне середовище ставить нові вимоги до розробки організаційно-економічного механізму управління конкурентоспроможністю підприємства, ефективність функціонування якого повинна забезпечуватися як під впливом удосконалення організації виробництва, праці та управління, так і спроможністю його пристосування до сучасних умов господарювання. Динамічні зміни середовища стимулює підприємство виробляти конкурентоспроможну продукцію для забезпечення ефективного функціонування. Механізм управління конкурентоспроможністю дозволяє вирішувати проблеми забезпечення високого рівня конкурентоспроможностіта посилення конкурентних перевагпідприємства.У зв'язку 3 цим особливої актуальності набуває проблема розробки організаційно-економічного механізму управління конкурентоспроможністю промислового підприємства.

На сьогоднішній день питаннями сутності та розробки організаційноекономічного механізму управління конкурентоспроможністю підприємства вивчались багатьма вітчизняними та закордонними авторами, серед яких: О. I. Волков, В. К. Скляренко [4], О. С. Коцюба [5], О. К. Добикіна, В. С. Рижиков, С. В. Касьянюк, А. А. Садєков, В. В. Цурик [7], М. П. Денисенко [6], С. А. Жданов [3]. Серед останніх наукових досліджень, присвячених проблемам оцінки та підвищення конкурентоспроможності підприємств, можна виділити праціН.П.Тарнавської, О.Є. Кузьміна, М.І. Долішнього, І.П. Тулєєва, Л.В Гриніва. Водночас багато питань розробки організаційно-економічного механізму управління конкурентоспроможністю залишаються невирішеними, що зумовлює необхідність пошуку сучасних шляхів забезпечення 
конкурентоспроможності 3 урахуванням особливостей промислових підприємств.

Постановка завдання. Метою статті $€$ розробка організаційноекономічного механізму управління конкурентоспроможністю промислових підприємств. Стаття присвячена розв’язанню наступних задач:

- розкрити сутність організаційно-економічного механізму управління конкурентоспроможністю підприємства;

- охарактеризувати принципи оцінки організаційно-економічного механізму управління конкурентоспроможністю підприємства;

- розробитиорганізаційно-економічний механізм управління конкурентоспроможністю підприємства.

Методологія. У роботі використані наступні методи дослідження:системного аналізу, синтезу (для виявлення теоретикометодичних i прикладних проблем формування механізму управління), комплексний метод оцінки конкурентоспроможності продукції.

Результати дослідження. Організаційно-економічний механізм управління промисловим підприємством - це сукупність організаційних i економічних важелів (кожному 3 яких властиві власні форми управлінського впливу), що чинять вплив на економічні і організаційні параметри системи управління підприємством, що сприяє формуванню та посиленню організаційно-економічного потенціалу, отриманню конкурентних переваг та ефективності діяльності підприємства в цілому [8]. Механізм управління містить у собі компоненти: принципи і задачі управління, методи, форми i інструменти управління, організаційну структуру управління підприємством та його персонал, інформацію та засоби їі обробки.

В структурі організаційно-економічного механізму виділяють три системи: систему забезпечення, функціональну систему, цільову систему.Цільова система організаційно-економічного механізму містить цілі та основні результати діяльності підприємства, а також критерії вибору і оцінки досягнення певних цілей і результатів діяльності підприємства. Зміст кожної 3 систем і кількість підсистем в кожній 3 систем організаційноекономічного механізму управління підприємством залежить від типу підприємства, сфери, масштабів діяльності, ступеня впливу зовнішнього середовища і результатів діяльності підприємства.

Організаційно-економічний механізм

управління конкурентоспроможністю підприємства пов'язаний 3 розробкою та ефективним функціональних підсистем управління:

1) управління маркетинговою діяльністю. Спочатку необхідно удосконалити наявну структуру маркетингового відділу, особливу увагу також варто приділити процесу вивчення ринку, дослідженню перспективних 
напрямів ведення збутової діяльності, а також дослідженню питання рівня конкурентоспроможності продукції, що виготовляється підприємством.

2) управління якістю. Одна $з$ найважливіших складових компонентів організаційно-економічного механізму забезпечення конкурентоспроможності підприємства. Якість товарів і послуг, може забезпечити фірмі значні конкурентні переваги на цільових ринках. Відсутність же науково обгрунтованих стратегій управління якістю продукції підприємства може позбавити його, з одного боку, вже завойованих конкурентних позицій на ринках, а з іншого - зробити неможливим ефективне ведення конкурентної боротьби на нових ринках, оскільки якість продукції, як відомо, є одним 3 головних конкурентних переваг товару;

3) управління виробничою діяльністю. Одна з важливих підсистем, під час розробки та функціонування якої необхідно у першу чергу звернути увагу на технічний рівень виробництва, який у свою чергу визначається станом технології та техніки. Для більшості виробничих підприємств актуальною $є$ проблема технічного оновлення, а також удосконалення методів та технології виробництва продукції, що в першу чергу пов'язано з необхідністю економії виробничих ресурсів та поліпшення рівня якості продукції, що випускається;

4) управління фінансовою діяльністю. Даний процес в свою чергу відображає уміння правильного розпорядження результатами діяльності, а також оптимізацію руху фінансових потоків, що забезпечує виконання життєво важливих для підприємства функцій;

5) управління персоналом підприємства. Саме від цієї підсистеми залежить і рівень продуктивності праці робітників, i якість робіт, що виконуються, i, як результат, ефективність роботи підприємства. Тому ефективний менеджмент персоналу забезпечує успішне функціонування підприємства як цілісної системи.

Під організаційно-економічним механізмом управління конкурентоспроможністю підприємства розуміють сукупність засобів та методів створення системи цілісного управління розвитком підприємства та результатами його діяльності, направленого на довгострокове забезпечення його конкурентних позицій на ринку [9].Основними принципами оцінки організаційно-економічного механізму управління конкурентоспроможністю підприємства є: загальносистемні, що зображено на рис. 1:

- комплексність - результати дослідження конкурентоспроможності підприємства повинні сполучати і оцінку ефективності процесу його адаптації до змінних умов функціонування, i ступінь реалізації стратегічного потенціалу, і конкурентні позиції підприємства відносно одного або декількох конкурентів, що розглядаються як база порівняння; 


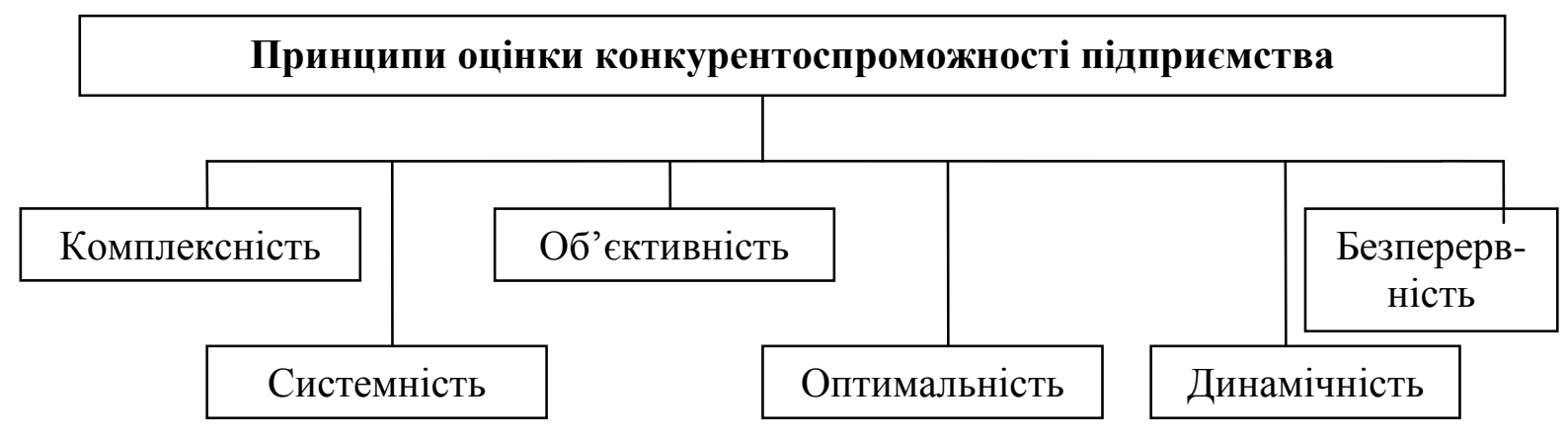

Рис.1.Принципи оцінки конкурентоспроможності підприємства Джерело [1,2]

- системність - основою для оцінки рівня конкурентоспроможності і розробки відповідних рекомендацій можуть виступати лише результати системного аналізу впливу чинників зовнішнього та внутрішнього середовища підприємства з урахуванням між факторних взаємозв'язків;

- об'єктивність - результати дослідження та оцінки конкурентоспроможності підприємства повинні базуватися на повній та достовірній інформації про зовнішні та внутрішні умови його функціонування і відображати реальні конкурентні позиції суб'єкта господарювання;

- динамічність - основним завданням дослідження конкурентоспроможності $\epsilon$ не статична оцінка фактичних конкурентних позицій підприємства на конкретний момент часу, а прогнозування їх змін та розробка на цій основі ефективних управлінських рішень;

- безперервність - процес дослідження та оцінки конкурентоспроможності та змін іiі рівня має носити безперервний характер (шляхом створення системи моніторингу ринку, чинників конкурентоспроможності, конкурентних позицій), оскільки дискретні оцінки не завжди дають можливість своєчасно зафіксувати стрибкоподібні зміни чинників конкурентоспроможності, оцінити можливі тенденції динаміки конкурентних позицій підприємства та своєчасно прийняти та реалізувати відповідні управлінські рішення;

- оптимальність - у відповідності 3 цим принципом об'єктом дослідження є не лише сам рівень конкурентоспроможності, але і ступінь ефективності його досягнення, тому конче необхідною $є$ комплексна оцінка шляхів досягнення певних конкурентних позицій з урахуванням як прямих витрат, пов'язаних 3 реалізацією заходів по регулюванню конкретного чинника, так і потенційних витрат на розвиток та підтримку конкурентної переваги в майбутньому.

Модель і структуру основних програмно-цільових блоків організаційноекономічного механізму розробили О.Є. Кузьмін, М.I. Долішній, І.П. Тулєєв та здійснили науково-методичні рекомендації та практичні рішення щодо вибору i реалізації конкретних організаційних, економічних та техніко- 
технологічних заходів для кожного 3 них, які сукупно створюють реальні передумови забезпечення конкурентних переваг підприємства в умовах нестабільного зовнішнього середовища і динамічних змін кон'юнктури ринку індустріальної техніки [10, с. 116].На основі розглянутих вище елементів був розроблений організаційно-економічний механізм управління конкурентоспроможністю підприємства, принципова блок-схема якого відображена на рис. 2.

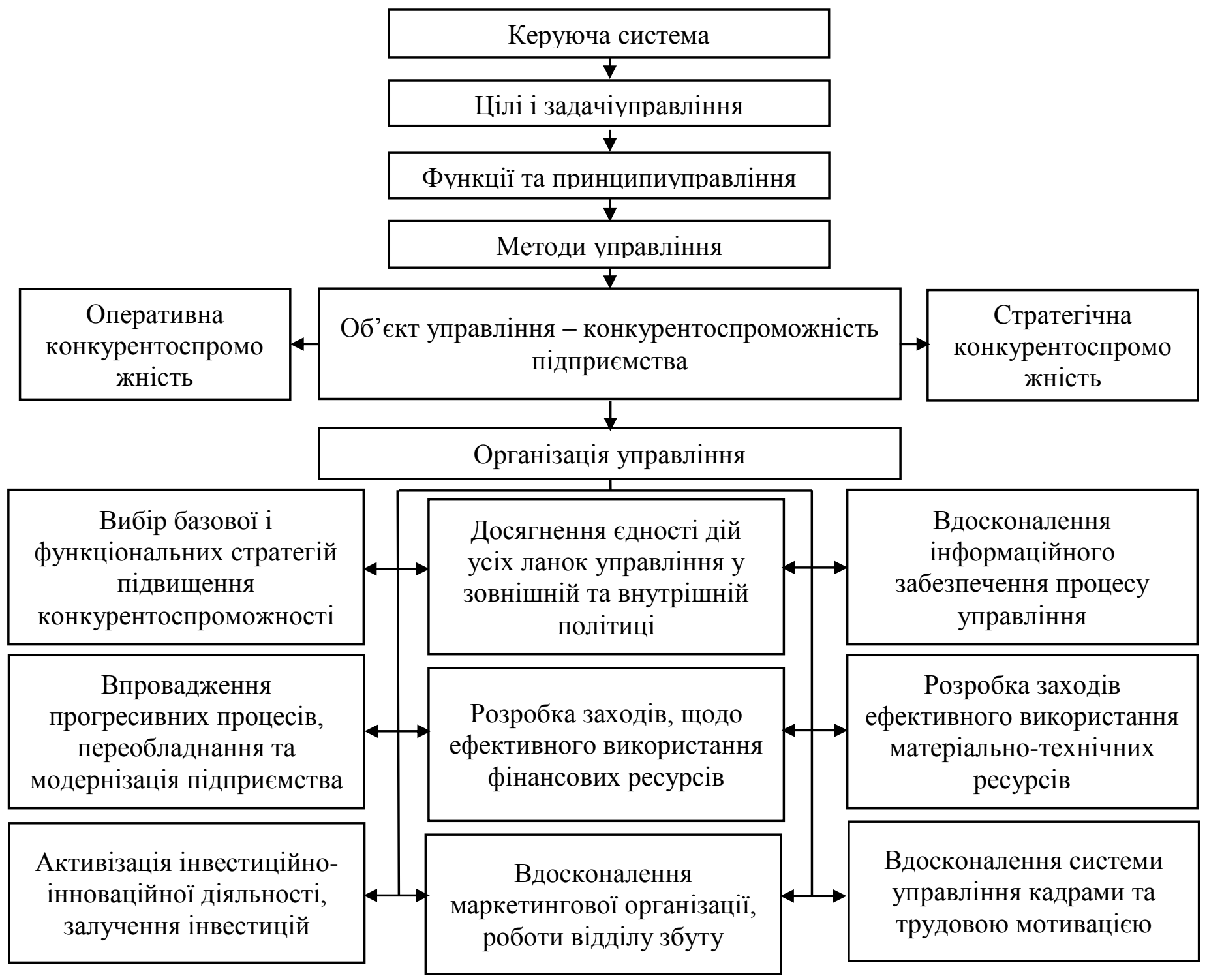

Рис. 2. Структура організаційно-економічного механізму управління конкурентоспроможністю промислового підприємства

Організаційно-економічнй механізм управління конкурентоспроможністю підприємства включає керуючу систему, цілі і задачі управління. При цьому, залежно від ситуації, цілями підприємства 
може бути підтримка конкурентоспроможності на зазначеному рівні, підвищення конкурентоспроможності, або іiі відновлення. Він являє собою специфічну багатофункціональну та багатокомпонентну систему, що складається 3 комплексу взаємопов'язаних блоків, схильних до впливу зовнішніх і внутрішніх факторів і утворюють певну цілісність. Організаційноекономічний механізм управління конкурентоспроможністю підприємства включає функції управління, реалізація яких здатна забезпечити досягнення поставлених перед керуючою системою цілей.

Після розробки організаційно-економічного механізму необхідно провести оцінку конкурентоспроможності підприємства комплексним методом. Він передбачає оцінювання ваги впливу кожної властивості на загальний рівень якості. Подані групи факторів впливають на конкурентоспроможність продукції. Серед них є ті, що мають ефект бажаний i небажаний. Оцінка факторів конкурентоспроможності продукції ПАТ «Легко» та основних конкурентів наведено в таблиці. Шкала оцінювання кожного з факторів конкурентоспроможності складає від 1 до 5 балів.

Таблиця

Характеристики факторів конкурентоспроможності напівфабрикатів ТМ «Легко» та основних конкурентів

\begin{tabular}{|c|c|c|c|c|c|c|c|}
\hline $\begin{array}{c}\text { Ко } \\
\text { Д }\end{array}$ & Найменування & $\begin{array}{c}\text { ПАТ } \\
\text { «Легко } \\
\text { » }\end{array}$ & $\begin{array}{c}\text { Бал } \\
\text { и }\end{array}$ & $\begin{array}{c}\text { TОВ } \\
\text { «Три } \\
\text { ведмеді } \\
\text { » }\end{array}$ & $\begin{array}{c}\text { Бал } \\
\text { и }\end{array}$ & $\begin{array}{c}\text { TМ } \\
\text { «Дригало } \\
\text { » }\end{array}$ & $\begin{array}{c}\text { Бал } \\
\text { и }\end{array}$ \\
\hline $\mathrm{K}_{1}$ & Собівартість & 75 & 5 & 65 & 4 & 71 & 3 \\
\hline $\mathrm{K}_{2}$ & Цінапродукції & 19000 & 4 & 18000 & 3 & 20000 & 5 \\
\hline $\mathrm{K}_{3}$ & $\begin{array}{l}\text { Середньорічнийрівеньзаробітн } \\
\text { ої плати (грн) }\end{array}$ & 2130 & 3 & 2475 & 5 & 2200 & 4 \\
\hline $\mathrm{K}_{4}$ & Ступіньохоплення ринку & 25,6 & 5 & 22,4 & 3 & 23 & 4 \\
\hline $\mathrm{K}_{5}$ & Наявністьзнижок & $\begin{array}{c}\text { немає } \\
\text { знижок }\end{array}$ & - & $\begin{array}{c}\text { немає } \\
\text { знижок }\end{array}$ & - & $\begin{array}{c}\text { немає } \\
\text { знижок }\end{array}$ & - \\
\hline $\mathrm{K}_{6}$ & Імідж товару & 5 & 5 & 5 & 5 & 5 & 5 \\
\hline $\mathrm{K}_{7}$ & Технічніфактори & 5 & 5 & 5 & 5 & 5 & 5 \\
\hline $\mathrm{K}_{8}$ & Якістьпродукції & 5 & 5 & 4 & 4 & 4 & 4 \\
\hline $\mathrm{K}_{9}$ & Сучаснеустаткування & 5 & 5 & 4 & 4 & 4 & 4 \\
\hline $\mathrm{K}_{10}$ & Доставка замовнику & - & - & - & - & - & - \\
\hline $\mathrm{K}_{11}$ & Гарантування рекламації & 4 & 4 & 4 & 4 & 4 & 4 \\
\hline $\mathrm{K}_{12}$ & $\begin{array}{l}\text { Комплексність процесу } \\
\text { виробництва }\end{array}$ & 4 & 4 & 4 & 4 & 4 & 4 \\
\hline & $\sum$ & - & 45 & - & 41 & - & 42 \\
\hline
\end{tabular}

Провівши оцінювання можна сказати, що кожна група факторів суттєво впливає на загальний результат якості. ПАТ «Легко» набрало найбільшу суму зважених показників конкурентоспроможності продукції порівняно 3 основними конкурентами. Тому, найбільший вплив мають фактори собівартості, якості та орієнтації діяльності підприємства на клієнта. 
Отже, для вдосконалення системи управління конкурентоспроможністю ПАТ «Легко» необхідно використовувати сучасні принципи менеджменту, маркетингу, забезпечення стратегічного підходу до їхньої діяльності. Провідною метою кожного підприємства, що хоче досягнути оптимального рівня конкурентоспроможності, є управління конкурентоспроможністю на основі самоорганізації 3 розвиненням властивостей адаптивності та інноваційності.

Висновки. В процесі дослідження підприємств харчової промисловості було виявлено наступні проблеми забезпечення конкурентоспроможності: неякісний менеджмент, низька активність й ефективність інноваційної діяльності, недосконалість бізнес-процесів, недостатність практичного досвіду управління конкурентоспроможністю. Науковою новизною отриманих результатів $\epsilon$ удосконалення науково-теоретичного обгрунтування та практичних підходів до розробки організаційно-економічного механізму управління конкурентоспроможністю підприємствами в ринкових умовах, що, на відміну від існуючих, передбачає вирішення проблем забезпечення конкурентоспроможності 3 урахуванням особливостей промислових підприємств.

Теоретичне та практичне значення результатів дослідження полягає в тому, що розроблений механізм управління конкурентоспроможністю підприємства дозволяє підвищити рівень конкурентоспроможності підприємства та досягти успіху в конкурентній боротьбі.

Перспективи подальших наукових розробок можуть бутиспрямовані на розробку методики оцінювання організаційно-економічного механізму управління конкурентоспроможністю підприємства 3 метою досягнення його стійкого розвитку. Результати дослідження формування організаційноекономічного механізму управління конкурентоспроможністю підприємства можуть бути використані в діяльності підприємств, як план розвитку підвищення конкурентоспроможності підприємств та збільшення сегменту цільового ринку.

\section{Література:}

1. Кобиляцький Л.С. Управління конкурентоспроможністю: Навчальний посібник/ Л.С. Кобиляцький - К.: Зовнішня торгівля, 2003. $-304 \mathrm{c}$.

2. Лифиц И. М. Основы стандартизации, метрологии, сертификации: Ученик / И.М. Лифиц - М.: Юрайт, 2009. - 399 с.

3. Жданов С. А. Механизмы экономического управления предприятием : учеб.пособие/ С. А. Жданов - М.: ЮНИТИ-ДАНА, 2002. - 319 с.

4. Волков О. И. Экономика предприятия: курс лекций / О. И. Волков, В. К. Скляренко- М.: ИНФРА-М, 2003. - 280 с. 
5. Грещак М. Г. Внутрішній економічний механізм підприємства : навч. посіб. / М. Г. Грещак, О. М. Гребешкова, О. С. Коцюба; за ред. М. Г. Грещака - К. : КНЕУ, 2001. - 228 c.

6. Денисенко М. П. Економіка підприємства: пошук шляхів розвитку : посіб. / М. П. Денисенко - К. : МАУП, 2002. - 80 с.

7. Садеков А. А. Управлениепредприятием в условияхкризиса : моногр. / А. А. Садеков, В. В. Цурик - Донецк : ДонГУЭТ, 2006. - 178 с.

8. Паламарчук О. M. Сутність та формуванняорганізаційноекономічногомеханізмууправлінняконкурентоспроможністюпідприємства [Електронний ресурс] - Режим доступу:

http://archive.nbuv.gov.ua/portal/soc_gum/evu/2011_17_2/Palamarchuk.pdf.

9. Кривов'язюк I. В. Проблеми формування організаційно-економічного механізму системи управління конкурентоспроможністю підприємства: [Електронний ресурс] Режим

доступу:http://mobile.pidruchniki.ws/1368051153556/ekonomika/problemi_formuvannya_organi zatsiynoekonomichnogo_mehanizmu_sistemi_upravlinnya_konkurentospromozhnistyu.

10.Кузьмін О. С. Конкурентоспроможність: проблеми науки і практики: монографія / О. Є. Кузьмін, М. І. Долішній, І. П. Булеєв, В. Г. Шинкаренкота ін. - Харків: ВД "ІНЖЕК", 2006. $-248 \mathrm{c}$. 